\title{
Effect of Spring Grazing Date and Stocking Rate on Sward Characteristics and Dairy Cow Production During Midlactation
}

\author{
E. Kennedy, ${ }^{*}{ }^{1}$ M. O’Donovan, ${ }^{*}$ J. P. Murphy, ${ }^{\star}$ L. Delaby, $\ddagger$ and F. P. O’Mara $\dagger^{2}$ \\ *Dairy Production Research Centre, Teagasc, Moorepark, Fermoy, Co. Cork, Ireland \\ †School of Agriculture, Food Science and Veterinary Medicine, NUI Dublin, Belfield, Dublin 4, Ireland \\ łInstitut National de la Recherche Agronomique (INRA), Unité Mixte de Recherche (UMR) Production du Lait, 35590 St. Gilles, France
}

\begin{abstract}
The objective of this study was to investigate the effect of initial spring grazing date and subsequent stocking rate on sward characteristics, grazing behavior, milk yield, and dry matter intake of spring-calving dairy cows during the main grazing season. Sixty-four spring-calving Holstein-Friesian dairy cows $(58 \pm 9 \mathrm{~d}$ in milk) were balanced and randomly assigned to 1 of 4 grazing treatments $(\mathrm{n}=16)$ between April 12, and July 3, 2004. Two swards, an early-grazed (E) sward and a late-grazed (L) sward had 2 stocking rates, high and medium, imposed across them. Cows grazing the E swards were stocked at $4.5 \mathrm{cows} / \mathrm{ha}$ (E4.5) and 5.5 cows/ha (E5.5), whereas cows grazing the L sward were stocked at 5.5 cows/ha (L5.5) and 6.4 cows/ha (L6.4). Sward characteristics, grazing behavior, and grass dry matter intake (GDMI) were investigated during the second (R2) and fourth grazing rotations (R4). Total dry matter yield was greater on L swards in R2. In R2, the E swards had a greater proportion of leaf as well as a lesser stem and dead dry matter yield. During R2, organic matter digestibility and crude protein content were greater on the E sward than the L sward. Preand postgrazing heights were greater for the L swards in R2 and R4. In R4, there was a larger leaf allowance on the E swards. Grazing time was greater and ruminating time lesser for animals grazing the $\mathrm{E}$ sward in R2. During R4, intake per bite was greater for the E5.5 and E4.5 treatments. Milk and solids-corrected milk yields as well as GDMI were greater for animals grazing the $\mathrm{E}$ sward in both R2 and R4. The results of the present study suggest that early grazing initially had a positive effect on sward quality and structure, which resulted in improved grazing behavior characteristics, increased GDMI, and increased milk production. During R4, sward quality and structure were similar between
\end{abstract}

Received June 13, 2006.

Accepted December 9, 2006.

${ }^{1}$ Corresponding author: Emer.Kennedy@teagasc.ie

${ }^{2}$ Present address: Teagasc HQ, Oakpark, Co. Carlow, Ireland. swards; thus, differences in grazing behavior were due to divergent daily herbage allowances. These results suggest that sward structure and quality as well as daily herbage allowance are important factors that influence animal performance and grazing behavior.

Key words: dairy cow, spring turnout date, sward profile, grazing behavior

\section{INTRODUCTION}

Grazed herbage can supply nutrients to dairy cows at a lesser cost than alternative feeds (Shalloo et al., 2004). Therefore, the objective of pasture-based systems must be to optimize the proportion of grazed grass in the diet of the dairy cow (Dillon et al., 2005). The greatest potential to do this exists in early spring and late autumn.

Allowing spring-calving dairy cows access to pasture earlier in lactation improves milk production (Kennedy et al., 2005). This practice also results in increased sward utilization and sward quality (O'Donovan et al. 2004). If grazing in spring is delayed, high herbage mass (HM) swards result, which are capable of supporting a high stocking rate (O'Donovan et al., 2004; Kennedy et al., 2006). If sward quality deteriorates in these high HM swards, milk production per animal may decrease.

Daily herbage allowance (DHA) is one of the major factors affecting the herbage intake of grazing animals. There is a strong curvilinear relationship between DHA and grass DMI (GDMI; Peyraud et al., 1996). On highly stocked swards, where DHA is restricted, animals are forced to graze deeper into the sward horizon consuming inferior-quality material in subsequent grazing rotations. This may affect the grazing behavior of the animals, as Newman et al. (1994) and McCarthy et al. (2007) concluded that a large component of herbage intake is behavioral. Newman et al. (1994) postulated that grazing behavior may be affected by many physical factors of the environment such as depth of the grazed horizon, sward density, and the vertical distribution of HM. Bite mass, one of the main determinants of intake 
rate, plays an important part in overall daily herbage intake (Phillips and Leaver, 1986) and has been shown to be influenced by sward structure (Laca et al., 1992).

The grazing hypothesis is that a greater stocking rate results in a greater grazing severity (O'Donovan et al., 2004), yet it may also lead to improved sward quality in subsequent grazing rotations. Grassland management for cows in spring is thus a complex interaction between 1) seeking to achieve early turnout so as to maximize annual GDMI, 2) ensuring that HM is not compromised by early turnout such that DHA is insufficient for high animal production, 3) ensuring high-quality herbage at turnout, 4) ensuring a sward structure that facilitates high intake rates by grazing cows, and 5) maintaining midseason sward quality through management in the early grazing season.

The interaction between sward and animal is an integral part of any grassland-based system. To maximize the contribution of grazed herbage to pasture-based dairy systems, a better understanding of the sward and the behavioral response of the animal is needed. The objective of this experiment was to investigate the effect of an early and delayed spring grazing date and subsequent stocking rate on sward structure, grazing behavior, milk yield, and GDMI of spring-calving dairy cows during 2 distinct periods between April and July (the main grazing season).

\section{MATERIALS AND METHODS}

The experiment was conducted at Moorepark Research Centre, Fermoy, Co. Cork, Ireland ( $50^{\circ} 7^{\prime} \mathrm{N} ; 8^{\circ} 16^{\prime}$ $\mathrm{W})$. The soil type is a free-draining, acid brown earth with a sandy loam-to-loam texture. A grassland site dominated by 2 - to 3 -yr-old perennial ryegrass (Lolium perenne L.) swards was used. A grass seed mixture of 3 late diploid cultivars (Twystar, Cornwall, and Gilford) was initially sown. No clover was present in the sward. Each treatment was applied for four 21-d rotations (84 d) from April 12 to July 3, 2004; thus, each paddock was grazed once every $21 \mathrm{~d}$. This was repeated on 4 occasions over the experimental period.

\section{Treatments and Experimental Design}

A grazing area of 14.6 ha was used to compare 4 grazing treatments: 2 swards with different initial grazing dates and 2 stocking rates (Table 1). The grazing area was divided into 4 large grazing plots. Half of each large plot was grazed once between February 16 and April 4 [(49 d) early grazed; E] to an average postgrazing rising plate meter height of $4.5 \mathrm{~cm}$ (SD 0.49). Surface damage was minimized during this period by removing animals when weather conditions were consid- ered inclement. The other half remained ungrazed from the previous October (late grazed; L). Within the earlyand late-grazing-date areas, subpaddocks were allocated to 2 stocking rates (high and medium), which were applied from April 12 to July 3. The experimental treatments were as follows: early medium (E4.5): earlygrazed sward with a medium stocking rate of 4.5 cows/ ha; early high (E5.5): early-grazed sward with a high stocking rate of $5.5 \mathrm{cows} / \mathrm{ha}$; late medium (L5.5): lategrazed sward with a medium stocking rate of 5.5 cows/ ha; late high (L6.4): late-grazed sward with a high stocking rate of 6.4 cows/ha. Within this experiment, the swards represented an early and a delayed start to the grazing season.

Animals in each herd were allocated an area allowance of $0.17,0.14,0.17$, and $0.15 \mathrm{ha} / \mathrm{d}$ for the E4.5, E5.5, L5.5, and L6.4 treatments, respectively. Each treatment was allocated an equal number of paddocks within the 4 large grazing plots. In total, 21 paddocks were allocated to each treatment, all of which were grazed consecutively during the experimental period. Residency time in each paddock was $24 \mathrm{~h}$; fresh herbage was allocated after the morning milking. All paddocks had an individual water supply. No concentrate was offered during the experimental period.

This paper is a component of a larger experiment (Kennedy et al., 2006) and will focus on sward structure, milk production, GDMI, and grazing behavior data from the 2 periods when grazing behavior was recorded. The first measurement period (R2) coincided with the second grazing rotation (May 2 to 22), whereas the second measurement period (R4) corresponded to rotation 4 (June 12 to July 3 ). The first series of grazing behavior collections commenced on May 5, and the second began on June 12. Production data from the entire experimental period is reported in Kennedy et al. (2006).

The first $\mathrm{N}$ fertilization (urea) was applied to all swards in mid-January at a rate of $60 \mathrm{~kg}$ of N/ha. Nitrogen (calcium ammonium nitrate) was reapplied to the early-grazed swards at the same rate immediately after their first grazing. No P and K applications were made to either sward because the soil index showed adequate concentrations. Nitrogen was applied at a rate of $60 \mathrm{~kg}$ of N/ha to each sward after grazing rotations 1 and 2 of the present study. The application rate was decreased to $40 \mathrm{~kg}$ of N/ha for rotations 3 and 4 .

\section{Animals}

Sixty-four cows were originally selected from the Moorepark general spring-calving herd. Thirty-two animals were primiparous, whereas the remaining 32 animals were multiparous (24 second-lactation animals and 8 animals in their third or greater lactation). The 
Table 1. Paddock layout and design from April 12 to July 3, 2004, of an experiment investigating effect of spring grazing date ( $\mathrm{E}$ or $\mathrm{L})$ and stocking rate $(\mathrm{H}$ or $\mathrm{M})$ on sward characteristics and dairy cow production during midlactation ${ }^{1}$

\begin{tabular}{|c|c|c|c|c|c|c|c|c|c|c|c|c|c|c|c|c|}
\hline & \multicolumn{4}{|c|}{1} & \multicolumn{4}{|c|}{2} & \multicolumn{4}{|c|}{3} & \multicolumn{4}{|c|}{4} \\
\hline & \multicolumn{2}{|c|}{$\mathrm{E}$} & \multicolumn{2}{|c|}{$\mathrm{L}$} & \multicolumn{2}{|c|}{$\mathrm{E}$} & \multicolumn{2}{|c|}{$\mathrm{L}$} & \multicolumn{2}{|c|}{$\mathrm{E}$} & \multicolumn{2}{|c|}{$\mathrm{L}$} & \multicolumn{2}{|c|}{$\mathrm{E}$} & \multicolumn{2}{|c|}{$\mathrm{L}$} \\
\hline & $\underset{(5.5)}{\mathrm{H}}$ & $\begin{array}{c}\mathrm{M} \\
(4.5)\end{array}$ & $\begin{array}{c}\mathrm{H} \\
(6.5)\end{array}$ & $\underset{(5.5)}{\mathrm{M}}$ & $\begin{array}{c}\mathrm{H} \\
(5.5)\end{array}$ & $\underset{(4.5)}{\mathrm{M}}$ & $\underset{(6.5)}{\mathrm{H}}$ & $\underset{(5.5)}{\mathrm{M}}$ & $\underset{(5.5)}{\mathrm{H}}$ & $\underset{(4.5)}{\mathrm{M}}$ & $\underset{(6.5)}{\mathrm{H}}$ & $\underset{(5.5)}{\mathrm{M}}$ & $\underset{(5.5)}{\mathrm{H}}$ & $\underset{(4.5)}{\mathrm{M}}$ & $\begin{array}{c}\mathrm{H} \\
(6.5)\end{array}$ & $\underset{(5.5)}{M}$ \\
\hline Paddock & $\begin{array}{l}1 \\
2 \\
3 \\
4\end{array}$ & $\begin{array}{l}1 \\
2 \\
3 \\
4\end{array}$ & $\begin{array}{l}1 \\
2 \\
3 \\
4\end{array}$ & $\begin{array}{l}1 \\
2 \\
3 \\
4\end{array}$ & $\begin{array}{l}5 \\
6 \\
7 \\
8 \\
9\end{array}$ & $\begin{array}{l}5 \\
6 \\
7 \\
8 \\
9\end{array}$ & $\begin{array}{l}5 \\
6 \\
7 \\
8 \\
9\end{array}$ & $\begin{array}{l}5 \\
6 \\
7 \\
8 \\
9\end{array}$ & $\begin{array}{l}10 \\
11 \\
12 \\
13 \\
14\end{array}$ & $\begin{array}{l}10 \\
11 \\
12 \\
13 \\
14\end{array}$ & $\begin{array}{l}10 \\
11 \\
12 \\
13 \\
14\end{array}$ & $\begin{array}{l}10 \\
11 \\
12 \\
13 \\
14\end{array}$ & $\begin{array}{l}15 \\
16 \\
17 \\
18 \\
19 \\
20 \\
21\end{array}$ & $\begin{array}{l}15 \\
16 \\
17 \\
18 \\
19 \\
20 \\
21\end{array}$ & $\begin{array}{l}15 \\
16 \\
17 \\
18 \\
19 \\
20 \\
21\end{array}$ & $\begin{array}{l}15 \\
16 \\
17 \\
18 \\
19 \\
20 \\
21\end{array}$ \\
\hline
\end{tabular}

${ }^{1} \mathrm{E}=$ early-grazed sward; $\mathrm{L}=$ late-grazed sward; $\mathrm{H}=$ high stocking rate (cows/ha); $\mathrm{M}$ = medium stocking rate (cows/ha).

animals assigned to the present study were previously assigned to an early-lactation feeding study (Kennedy et al., 2005). The production data from the last $3 \mathrm{wk}$ of the previous study were used in the randomization of animals to experimental groups for this study. Previous treatment was used as a balancing factor. Four groups of cows $(\mathrm{n}=16)$ were balanced on lactation number (1.9 \pm 1.47 ; mean \pm SD), DIM to April $1,(58 \pm 9$ d; mean \pm $\mathrm{SD})$, milk yield ( $28.7 \pm 5.47 \mathrm{~kg} / \mathrm{d}$; mean $\pm \mathrm{SD})$, milk fat concentration (3.96 $\pm 0.426 \%$; mean $\pm \mathrm{SD})$, milk protein concentration ( $3.21 \pm 0.223 \%$; mean $\pm \mathrm{SD})$, milk lactose concentration $(4.88 \pm 0.154 \%$; mean $\pm \mathrm{SD})$, solidscorrected milk $(\mathbf{S C M})$ yield $(26.9 \pm 4.82 \mathrm{~kg} / \mathrm{d}$; mean \pm $\mathrm{SD}), \mathrm{BW}(511 \pm 52.4 \mathrm{~kg}$; mean $\pm \mathrm{SD})$, and BCS (2.82 \pm 0.35 ; mean $\pm \mathrm{SD}$ ).

One cow from the 64 used in the previous experiment did not transfer to the present study because of ill health; a replacement animal of equal parity was substituted for this animal. Eight nonexperimental cows were used in this study to impose the stocking rates on the late-grazed sward; 4 primiparous and 4 multiparous animals were used to maintain the lactation number equilibrium within each of these 2 treatments. No data collected from the replacement and nonexperimental animals were used in the analysis of this study.

\section{Sward Measurements}

Herbage mass $(>4.0 \mathrm{~cm})$ was determined twice weekly by cutting 2 strips per paddock $(1.2 \mathrm{~m}$ wide $\times 10 \mathrm{~m}$ long) with a motor Agria (Etesia UK Ltd., Warwick, UK). Ten grass height measurements were recorded before and after harvesting on each cut strip using an electronic plate meter (Urban and Caudal, 1990) with a plastic plate $\left(30 \times 30 \mathrm{~cm}\right.$ and $4.5 \mathrm{~kg} / \mathrm{m}^{2}$; Agrosystèmes, Choiselle, France). This allowed the calculation of the sward density [HM (pregrazing DM yield/ha)/(precut- ting height - postcutting height); $\mathrm{kg}$ of $\mathrm{DM} / \mathrm{cm}$ per ha]. The harvested material from each cut strip was collected, weighed, and sampled. A subsample (100 g) was dried overnight at $90^{\circ} \mathrm{C}$ to determine DM. Herbage from the 2 strips was bulked; a subsample (approximately $100 \mathrm{~g}$ ) was taken and stored at $-20^{\circ} \mathrm{C}$ before being freeze-dried and milled in advance of chemical analysis. Samples were bulked by week and analyzed according to treatment.

Pre- and postgrazing sward heights were measured daily with a rising plate meter; 35 measurements were taken per treatment across the 2 diagonals of the paddock. The measured pregrazing sward height, multiplied by the mean sward density was used to calculate the daily herbage allowance of the herd. The calculation method specified by Delaby and Peyraud (1998) was applied to assess the mass production and utilization of herbage.

During periods of GDMI measurement, further sward measurements were taken in addition to these standard sward measurements. Pregrazing HM $<4.0 \mathrm{~cm}$ was measured within the cut strip by harvesting, to ground level, the herbage that remained following HM determination $(>4.0 \mathrm{~cm})$ using a $0.5 \times 0.2 \mathrm{~m}$ quadrat. All collected material was washed to remove any soil contamination and dried overnight at $90^{\circ} \mathrm{C}$ in a forced-air oven to determine DM. Pre- and postgrazing extended tiller heights (ETH) and extended sheath heights (ESH) were measured on 100 primary tillers across the diagonals of each of the 4 treatment paddocks using a graduated ruler. The ETH was measured from ground level to the highest point of the tiller. The ESH was measured from ground level to the point of the highest ligula (longest leafed sheath). Free leaf lamina (FLL) was calculated by subtracting the ESH from the ETH. Preand postgrazing measurements were taken on the same paddock twice weekly during the measurement period. 
The morphological composition of the herbage was determined weekly for each treatment during the measurement periods. Twenty handfuls of herbage (approximately $150 \mathrm{~g}$ ) were cut at random to ground level with a scissors before grazing. By securing the sample with an elastic band and placing it in a bag, the vertical structure of the cut sward was preserved. The fresh herbage was frozen immediately and later separated. The sample was cut into 2 portions, $>4.0 \mathrm{~cm}$ and $<4.0$ $\mathrm{cm}$. Each individual layer was then separated into leaf, stem (including true stem, pseudostem, and flower head, if present), and dead material. Each constituent was dried overnight in an oven at $90^{\circ} \mathrm{C}$ to determine morphological composition on a DM basis. The proportions, yields, and allowances of the leaf, stem, and dead material were then calculated.

Tiller density was calculated by counting out 100 random tillers from the samples cut to ground level. The dry weight of the tillers was measured after ovendrying at $90^{\circ} \mathrm{C}$ overnight. Tiller density (tillers $/ \mathrm{m}^{2}$ ) was calculated using the following equation: total DM yield [i.e., yield $>4.0 \mathrm{~cm}$ and $<4.0 \mathrm{~cm} \div$ (weight of one tiller, $\mathrm{kg}) \times 10,000$ ] (Jewiss, 1993).

\section{Animal Measurements}

Grazing Behavior. Grazing behavior data were collected from all cows across each of the 4 grazing treatments. Data were collected over two 24 -h periods. Fiftyfour and 61 usable individual grazing behavior recordings were obtained during R2 and R4, respectively. Following the morning milking, 3 cows from each grazing treatment were fitted with IGER (Institute of Grassland and Environmental Research) behavior recorders (Rutter et al., 1997). If the data file collected from a cow was deemed unreadable following the 24 -h period, the animal had a recorder fitted for a further $24 \mathrm{~h}$. Following recording, jaw movements were analyzed using Graze analysis software (Rutter, 2000). Total grazing, ruminating, and idling times as well as the number of prehensions and mastications were measured using this software. Additionally, the numbers of grazing and ruminating bouts were counted, as well as the number of boli within each ruminating bout. Handling time was calculated as grazing time plus ruminating time, intake/minute was calculated as [GDMI $(\mathrm{kg} / \mathrm{d}) \times 1,000] /$ grazing time and intake/bite was calculated as [GDMI $(\mathrm{kg} / \mathrm{d}) \times 1,000$ ]/grazing prehensions per d. Each behavior recording was individually linked to a corresponding DMI measurement period (i.e., the GDMI period closest to the date when grazing behavior was recorded).

Milk Production and Live Weight. Individual milk yields (kg) were recorded daily. Milking took place at 0700 and $1600 \mathrm{~h}$ daily during the study. Milk fat, pro- tein, and lactose were determined from one successive a.m. and p.m. sample taken during each week. The concentrations of these constituents were determined using a MilkoScan 203 (Foss Electric, Hillerød, Denmark). Solids-corrected milk yield was calculated using the equation of Tyrell and Reid (1965). All cows were weighed weekly. Each BW was recorded electronically using portable weighing scales and the Winweigh software package (Tru-test Limited, Auckland, New Zealand). Body condition score (Lowman et al., 1976) was recorded by the same observer once every $3 \mathrm{wk}$ from the first week of the experiment.

Intake Estimation. Individual GDMI was estimated on 3 occasions during the 2 grazing behavior recording periods using the $n$-alkane technique (Mayes et al., 1986) as modified by Dillon and Stakelum (1989). All cows were dosed twice daily, before milking, for 12 consecutive days with a paper filter or bung (Carl Roth, $\mathrm{GmbH}$ and Co. KG, Karlsruhe, Germany) containing $500 \mathrm{mg}$ of dotriacontane $\left(\mathrm{C}_{32}\right)$. From the seventh day of dosing, fecal grab samples were collected from each cow twice daily for the remaining $6 \mathrm{~d}$. The fecal grab samples were then bulked (10 g of each collected sample) and dried for $48 \mathrm{~h}$ in a $40^{\circ} \mathrm{C}$ oven in preparation for chemical analysis.

In conjunction with the fecal collection, the diet of the animals was also sampled. Herbage representative of that grazed (following close observation of the grazing animals' previous defoliation) was manually collected from each paddock before morning grazing on $\mathrm{d} 6$ to 11 (inclusive) of the intake measurement period. Two samples of approximately 25 individual grass snips were taken from each paddock with a Gardena hand shears (Accu 60, Gardena International GmbH, Ulm, Germany). The ratio of herbage $\mathrm{C}_{33}$ (tritriacontane) to dosed $\mathrm{C}_{32}$ was used to estimate intake. The n-alkane concentration was determined as described by Dillon (1993).

\section{Chemical Analyses}

The pregrazing herbage samples composited for each measurement week and each treatment were freezedried and milled through a 1-mm sieve. Samples were analyzed for DM, ash, ADF, NDF (Van Soest, 1963), and CP contents (Leco FP-428; Leco Australia Pty. Ltd., Baulkham Hills, New South Wales, Australia) as well as in vitro OM digestibility (OMD; Morgan et al., 1989).

\section{Statistical Analysis}

All statistical analyses were carried out using SAS (SAS Institute, 2002). All sward measurements were analyzed by ANOVA, using treatment as the effect $(\mathrm{i}=$ 
1 to 4). The orthogonal contrasts between early- and late-grazed swards are also presented in the tables.

All animal variables were analyzed using a repeated measures model (PROC MIXED). Although Rook and Penning (1991) demonstrated that grazing activities are more synchronized than expected at random, cows were considered to be independent, because the behavior of isolated individuals and groups has not proved to be different (Rook and Penning, 1991).

Daily milk yield, milk composition, DMI, grazing behavior, BW, and BCS [n = 54 (R2) and $\mathrm{n}=61(\mathrm{R} 4)]$ were analyzed with the following model:

$$
\mathrm{Y}_{\mathrm{ij}}=\mu+\mathrm{G}_{\mathrm{i}}+\mathrm{B}_{\mathrm{j}}+\mathrm{b}_{1} \mathrm{X}_{\mathrm{ij}}+\mathrm{e}_{\mathrm{ij}}
$$

where $Y_{i j}$ represents the response of the animal in parity $i$ to treatment $j ; \mu$ is the mean; $G_{i}$ is the grazing treatment ( $\mathrm{i}=1$ to 4$) ; \mathrm{B}_{\mathrm{j}}$ is the behavior round $(\mathrm{j}=1$ to $2) ; b_{1} X_{i j}$ is the respective preexperimental milk yield/ composition or $\mathrm{BW}$ variable, and $\mathrm{e}_{\mathrm{ij}}$ is the residual error term.

\section{RESULTS}

\section{Weather}

Total rainfall was less than the 10 -yr average for the months of April (64.5 mm), May (42.9 mm), and July $(46.6 \mathrm{~mm}$ ) by $11.6,29.9$, and $6.8 \mathrm{~mm}$, respectively; however, rainfall was twice the average during June $(+29.2$ $\mathrm{mm})$. Mean air temperatures for April $\left(8.8^{\circ} \mathrm{C}\right)$ and May $\left(11.4^{\circ} \mathrm{C}\right)$ concurred with the previous $10-\mathrm{yr}$ average. June temperatures $\left(15^{\circ} \mathrm{C}\right)$ surpassed the 10 -yr average by $+1.7^{\circ} \mathrm{C}$ but July $\left(14.3^{\circ} \mathrm{C}\right)$ was $1^{\circ} \mathrm{C}$ colder than average. Total sunshine hours were less than average for all months except May, when the average total sunshine hours were almost $9 \mathrm{~h}$ greater than the 10 -yr average. However, these conditions had no adverse effect on grass growth or grazing conditions.

\section{Sward Characteristics}

During R2, pre- and postgrazing compressed sward heights (Tables 2 and 3$)$ were higher $(P<0.001)$ for the late-grazed sward than the early-grazed sward. The pregrazing ETH, ESH, and FLL heights of the lategrazed sward were higher $(+11.6,6.9$, and $4.7 \mathrm{~cm}$, respectively; $P<0.001$ ) than that of the early-grazed sward during R2. When the leaf:stem ratio was calculated, the ratio of leaf to stem was greater $(P<0.001)$ for the early-grazed sward $(+0.7)$ compared with the late-grazed sward (1.32). The postgrazing ETH, ESH, and FLL heights measured on the late-grazed sward were higher $(4.5,3.4$, and $1.1 \mathrm{~cm}$, respectively; $P<0.001$ ) than that of the early-grazed sward.
Pregrazing HM (DM yield $>4.0 \mathrm{~cm} ; P<0.001$ ) was greater $(+1,055 \mathrm{~kg}$ of $\mathrm{DM} / \mathrm{ha})$ for the L6.4 and L5.5 treatments than the E5.5 and E4.5 treatments throughout R2 (Table 2). Dry matter yield $<4.0 \mathrm{~cm}$ was also greater $(+302 \mathrm{~kg}$ of DM/ha; $P<0.01)$ on the late-grazed swards. Although leaf yield $>4.0 \mathrm{~cm}$ was greater $(P<$ $0.05)$ for the late-grazed sward ( $+518 \mathrm{~kg}$ of DM/ha), the early-grazed sward had a larger $(+0.10 \% ; P<0.05)$ leaf proportion (Table 4). Sward dead proportion, dead yield, and dead allowance $>4.0 \mathrm{~cm}$ were greater $(+0.07,+268$ $\mathrm{kg}$ of DM/ha, and $+1.9 \mathrm{~kg}$ of DM/d, respectively; $P<$ 0.001 ) for animals grazing the late-grazed sward during R2 (Table 4).

The early-grazed swards had greater ash $(P<0.01$; Table 2), OMD $(P<0.001)$, and CP $(+40.6 \mathrm{~g} / \mathrm{kg} ; P<$ $0.05)$ contents; however, the late-grazed swards recorded greater NDF $(+37.0 \mathrm{~g} / \mathrm{kg})$ during R2.

Because DM yield was greater for the late-grazed treatments, DHA was $(P<0.05)$ greater for the lategrazed sward $(+4.2 \mathrm{~kg}$ of $\mathrm{DM} / \mathrm{d})$ compared with the early-grazed sward (22.7 kg of DM/cow). Unlike all the other parameters, however, there was no significant difference between the E4.5 and the L6.4 treatments in DHA offered. Sward utilization was greater $(+0.15$; $P<0.001$ ) on the early-grazed sward compared with the late-grazed sward.

During R4, pre- and postgrazing sward height, DHA, and sward utilization were unaffected by the initial grazing date. There was a difference $(P<0.05)$ between the pregrazing sward height of the E5.5 $(11.9 \mathrm{~cm})$ and L5.5 $(14.1 \mathrm{~cm})$ treatments. Postgrazing sward height was higher $(P<0.001)$ for both the E4.5 and L5.5 treatments when compared with the E5.5 and L6.4 treatments.

There was no difference in pregrazing herbage mass $>4.0 \mathrm{~cm}$ between the high $(2,008 \mathrm{~kg} / \mathrm{ha})$ and medium stocking rate treatments $(2,820 \mathrm{~kg} / \mathrm{ha})$. Both dead proportion $(P<0.05)$ and yield $(P<0.01)<4.0 \mathrm{~cm}$ were greater on the late-grazed sward compared with the early-grazed sward. The number of tillers $/ \mathrm{m}^{2}$ was greater $(P<0.05)$ on the early-grazed sward $(9,150$ tillers $\left./ \mathrm{m}^{2}\right)$ compared with the late-grazed sward $(7,154$ tillers $/ \mathrm{m}^{2}$ ).

Pregrazing ETH and FLL heights measured on the L5.5 sward were higher $(P<0.05)$ than all other treatments. The treatments stocked at a medium stocking rate had higher $(P<0.001)$ postgrazing ETH and ESH $(+2.7$ and $+2.1 \mathrm{~cm}$, respectively) than the highly stocked treatments $(9.0$ and $6.4 \mathrm{~cm}$, respectively). Postgrazing FLL was higher $(P<0.001)$ on the E4.5 sward $(3.5 \mathrm{~cm})$ compared with the other 3 swards $(2.8 \mathrm{~cm})$.

There was no significant effect of initial grazing date or stocking rate on sward chemical composition. Postgrazing sward height and DHA were greater $(P<0.001)$ 
Table 2. Effect of 4 grazing treatments differing in initial grazing date and stocking rate on pregrazing herbage measurements, allowance, and chemical composition during rotations 2 and 4 of the main grazing season ${ }^{1}$

\begin{tabular}{|c|c|c|c|c|c|c|c|c|c|}
\hline Item & \multicolumn{5}{|c|}{ Treatment } & \multicolumn{3}{|c|}{ Grazing date } & SED \\
\hline \multicolumn{10}{|l|}{ Rotation 2} \\
\hline \multicolumn{10}{|l|}{ Pregrazing sward height, cm } \\
\hline Compressed sward height & $14.5^{\mathrm{b}}$ & $14.4^{\mathrm{b}}$ & $18.8^{\mathrm{a}}$ & $18.1^{\mathrm{a}}$ & $* * *$ & 14.5 & 18.5 & $* * *$ & 0.44 \\
\hline Extended tiller & $17.9^{\mathrm{b}}$ & $18.0^{\mathrm{b}}$ & $29.9^{\mathrm{a}}$ & $29.3^{\mathrm{a}}$ & $* * *$ & 18.0 & 29.6 & $* * *$ & 2.39 \\
\hline Extended sheath & $5.9^{\mathrm{b}}$ & $6.8^{\mathrm{b}}$ & $12.5^{\mathrm{a}}$ & $14.2^{\mathrm{a}}$ & $* * *$ & 6.4 & 13.3 & $* * *$ & 1.12 \\
\hline Leaf:stem ratio & $2.27^{\mathrm{a}}$ & $1.76^{\mathrm{b}}$ & $1.50^{\mathrm{c}}$ & $1.13^{\mathrm{d}}$ & $* * *$ & 2.02 & 1.32 & $* * *$ & 0.266 \\
\hline DM yield $<4.0 \mathrm{~cm}$, per ha & $2,087^{\mathrm{b}}$ & $2,515^{\mathrm{a}}$ & $2,590^{\mathrm{a}}$ & $2,617^{\mathrm{a}}$ & $* *$ & 2,301 & 2,603 & ** & 98.7 \\
\hline DHA $>4.0 \mathrm{~cm}$, per cow & $25.6^{\mathrm{a}}$ & $19.9^{\mathrm{b}}$ & $29.6^{\mathrm{a}}$ & $24.3^{\mathrm{ab}}$ & * & 22.7 & 26.9 & * & 2.14 \\
\hline \multicolumn{10}{|l|}{ Chemical composition, $\mathrm{g} / \mathrm{kg}$} \\
\hline OM digestibility & $871.3^{\mathrm{b}}$ & $874.0^{\mathrm{b}}$ & $851.6^{\mathrm{a}}$ & $850.5^{\mathrm{a}}$ & $* *$ & 872.6 & 851.0 & $* * *$ & 0.58 \\
\hline Ash & $85.8^{\mathrm{a}}$ & $85.6^{\mathrm{a}}$ & $65.5^{\mathrm{b}}$ & $62.2^{\mathrm{b}}$ & $* *$ & 85.7 & 63.8 & $* *$ & 0.90 \\
\hline $\mathrm{CP}$ & 229.3 & 228.5 & 187.1 & 189.4 & NS & 228.9 & 188.3 & * & 7.14 \\
\hline \multicolumn{10}{|l|}{ Rotation 4} \\
\hline Extended tiller & $23.0^{\mathrm{b}}$ & $21.8^{\mathrm{b}}$ & $25.0^{\mathrm{a}}$ & $22.5^{\mathrm{b}}$ & $*$ & 22.4 & 23.7 & $\dagger$ & 2.55 \\
\hline Extended sheath & 10.7 & 9.4 & 10.8 & 10.3 & NS & 10.1 & 10.6 & NS & 1.57 \\
\hline Leaf:stem ratio & 1.37 & 1.48 & 1.57 & 1.47 & NS & 1.43 & 1.52 & NS & 0.299 \\
\hline \multicolumn{10}{|c|}{ Herbage yield/allowance, $\mathrm{kg}$ of DM } \\
\hline DM yield $>4.0 \mathrm{~cm}$, per ha & $3,045^{\mathrm{a}}$ & $2,121^{\mathrm{bc}}$ & $2,594^{\mathrm{ab}}$ & $1,894^{\mathrm{c}}$ & * & 2,583 & 2,244 & NS & 223.3 \\
\hline DM yield $<4.0 \mathrm{~cm}$, per ha & 2,839 & 3,144 & 3,368 & 3,156 & NS & 2,991 & 3,262 & NS & 164.3 \\
\hline DHA $>4.0 \mathrm{~cm}$, per cow & $30.8^{\mathrm{a}}$ & $21.2^{\mathrm{bc}}$ & $26.2^{\mathrm{ab}}$ & $17.2^{\mathrm{c}}$ & $* *$ & 26.0 & 21.7 & $\dagger$ & 2.08 \\
\hline \multicolumn{10}{|l|}{ Chemical composition, g/kg } \\
\hline OM digestibility & 837.6 & 848.7 & 836.7 & 837.9 & NS & 843.2 & 837.3 & NS & 11.12 \\
\hline Ash & 73.9 & 76.7 & 79.8 & 78.8 & NS & 75.3 & 79.3 & NS & 2.15 \\
\hline $\mathrm{CP}$ & 251.8 & 260.8 & 242.6 & 246.7 & NS & 256.3 & 244.6 & NS & 7.41 \\
\hline $\mathrm{NDF}$ & 376.7 & 365.8 & 392.0 & 386.3 & NS & 371.2 & 389.1 & NS & 17.64 \\
\hline $\mathrm{ADF}$ & 218.0 & 207.7 & 212.3 & 215.4 & NS & 212.8 & 213.8 & NS & 8.45 \\
\hline
\end{tabular}

${ }^{\mathrm{a}-\mathrm{d}}$ Values in the same row not sharing a common superscript are different.

${ }^{1}$ E5.5 = early-grazed sward, high stocking rate $(5.5$ cows/ha); E4.5 = early-grazed sward, medium stocking rate $(4.5$ cows/ha); L6.4 = lategrazed sward, high stocking rate (6.4 cows/ha); L5.5 = late-grazed sward, medium stocking rate (5.5 cows/ha); SED = standard error of the difference; $\mathrm{DHA}=$ daily herbage allowance.

$\dagger P \leq 0.10 ; * P<0.05 ; * * P<0.01 ; * * * P<0.001$.

Table 3. Effect of 4 grazing treatments differing in initial grazing date and stocking rate on postgrazing sward values ${ }^{1}$

\begin{tabular}{|c|c|c|c|c|c|c|c|c|c|}
\hline \multirow[b]{2}{*}{ Item } & \multicolumn{5}{|c|}{ Treatment } & \multicolumn{3}{|c|}{ Grazing date } & \multirow[b]{2}{*}{ SED } \\
\hline & $\mathrm{E} 4.5$ & E5.5 & L5.5 & L6.4 & Significance & Early & Late & Significance & \\
\hline \multicolumn{10}{|l|}{ Rotation 2} \\
\hline \multicolumn{10}{|l|}{ Postgrazing sward height, $\mathrm{cm}$} \\
\hline Compressed sward height & $5.9^{\mathrm{b}}$ & $5.1^{\mathrm{b}}$ & $8.4^{\mathrm{a}}$ & $7.9^{\mathrm{a}}$ & $* * *$ & 5.5 & 8.2 & $* * *$ & 0.41 \\
\hline Extended tiller & $8.8^{\mathrm{b}}$ & $8.4^{\mathrm{b}}$ & $13.2^{\mathrm{a}}$ & $13.0^{\mathrm{a}}$ & $* * *$ & 8.6 & 13.1 & $* * *$ & 1.33 \\
\hline Extended sheath & $5.5^{\mathrm{b}}$ & $5.7^{\mathrm{b}}$ & $8.7^{\mathrm{a}}$ & $9.2^{\mathrm{a}}$ & $* * *$ & 5.6 & 9.0 & $* * *$ & 1.09 \\
\hline Utilization, $\%$ & $0.82^{\mathrm{a}}$ & $0.89^{\mathrm{a}}$ & $0.70^{\mathrm{b}}$ & $0.73^{\mathrm{b}}$ & $* *$ & 0.86 & 0.71 & $* * *$ & 0.034 \\
\hline \multicolumn{10}{|l|}{ Rotation 4} \\
\hline \multicolumn{10}{|l|}{ Postgrazing sward height, $\mathrm{cm}$} \\
\hline Compressed sward height & $6.6^{\mathrm{a}}$ & $5.0^{\mathrm{b}}$ & $6.5^{\mathrm{a}}$ & $5.5^{\mathrm{b}}$ & $* * *$ & 5.8 & 6.0 & NS & 0.41 \\
\hline Extended tiller & $11.9^{\mathrm{a}}$ & $9.0^{\mathrm{b}}$ & $11.5^{\mathrm{a}}$ & $9.0^{\mathrm{b}}$ & $* * *$ & 10.5 & 10.3 & NS & 1.32 \\
\hline Extended sheath & $8.4^{\mathrm{a}}$ & $6.4^{\mathrm{b}}$ & $8.6^{\mathrm{a}}$ & $6.3^{\mathrm{b}}$ & $* * *$ & 7.4 & 7.5 & NS & 1.15 \\
\hline Utilization, \% & $0.72^{\mathrm{c}}$ & $0.88^{\mathrm{a}}$ & $0.75^{\mathrm{bc}}$ & $0.83^{\mathrm{ab}}$ & $*$ & 0.80 & 0.79 & NS & 0.049 \\
\hline
\end{tabular}

${ }^{\mathrm{a}-\mathrm{c}}$ Values in the same row not sharing a common superscript are different.

${ }^{1}$ E5.5 = early-grazed sward, high stocking rate (5.5 cows/ha); E4.5 = early-grazed sward, medium stocking rate (4.5 cows/ha); L6.4 = lategrazed sward, high stocking rate (6.4 cows/ha); L5.5 = late-grazed sward, medium stocking rate (5.5 cows/ha); SED = standard error of the difference.

$* P<0.05 ; * * P<0.01 ; * * * P<0.001$ 
Table 4. Effect of 4 grazing treatments differing in initial grazing date and stocking rate on the morphological composition of the sward greater than and less than $4.0 \mathrm{~cm}$ during rotations 2 and 4 of the main grazing season ${ }^{1}$

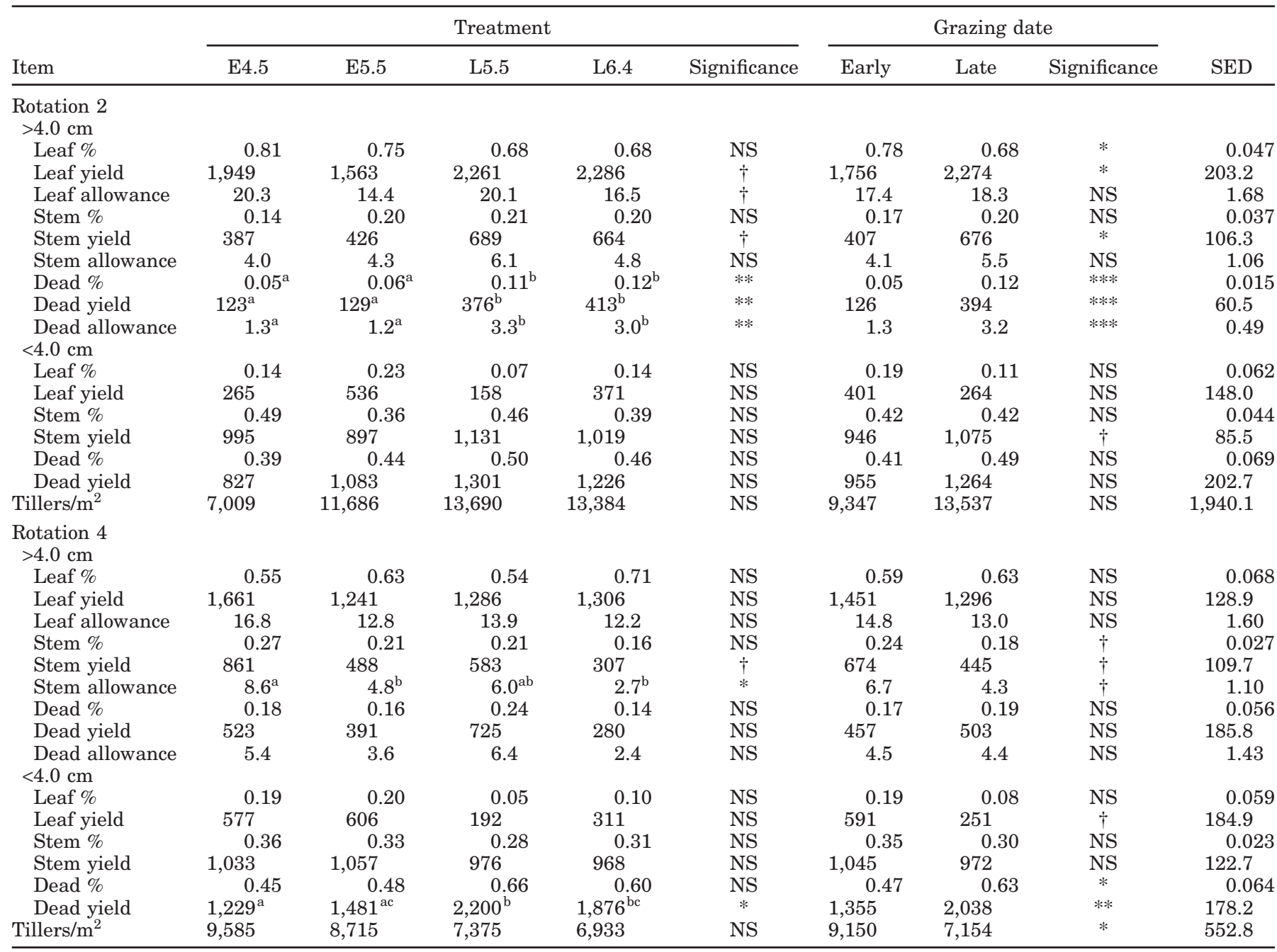

${ }^{\mathrm{a}-\mathrm{c}}$ Values in the same row not sharing a common superscript are different.

${ }^{1}$ E5.5 = early-grazed sward, high stocking rate (5.5 cows/ha); E4.5 = early-grazed sward, medium stocking rate (4.5 cows/ha); L6.4 = lategrazed sward, high stocking rate (6.4 cows/ha); L5.5 = late-grazed sward, medium stocking rate (5.5 cows/ha); SED = standard error of the difference.

$\dagger P \leq 0.1 ; * P<0.05 ; * * P<0.01 ; * * * P<0.001$.

for both the E4.5 and L5.5 treatments compared with the E5.5 and L6.4 treatments.

\section{Herbage Intake and Grazing Behavior}

Grass DMI was greater $(P<0.01)$ for the E4.5 treatment animals $(18.6 \mathrm{~kg}$ of $\mathrm{DM} / \mathrm{d})$ compared with all other treatments $(-1.9 \mathrm{~kg}$ of DM/d) during R2 (Table 5). Grazing time was highest $(P<0.05)$ for $\mathrm{E} 4.5(627 \mathrm{~min} / \mathrm{d})$. In contrast, the animals grazing the E5.5 treatment recorded the least number of ruminating mastications $(25,392$ mastications/d) and the lowest ruminating time $(400 \mathrm{~min} / \mathrm{d})$. Idling time of animals from the E5.5 treatment $(455 \mathrm{~min} / \mathrm{d})$ was greater $(P<0.05)$ than all other treatments $(397 \mathrm{~min} / \mathrm{d})$. Idling mastications were less for the E4.5 animals (803 mastications/d) than the E5.5 and L5.5 treatment animals (1,133 mastications/d).

Cows grazing the early-grazed sward had a greater $(P<0.01)$ grazing time $(620 \mathrm{~min} / \mathrm{d})$ than those grazing the late-grazed sward $(588 \mathrm{~min} / \mathrm{d})$. The L5.5 treatment animals had the highest number of ruminating mastications (32,318 mastications/d), which corresponded to the longest rumination time $(473 \mathrm{~min} / \mathrm{d})$. Ruminating bout duration was greater $(P<0.05)$ for animals grazing the late-grazed sward $(+5 \mathrm{~min} / \mathrm{d})$ compared with animals grazing the early-grazed sward $(34 \mathrm{~min} / \mathrm{d})$. Total mastications were greater $(P<0.001)$ for animals grazing the late-grazed sward ( $+5,789$ mastications/d) com- 
Table 5. Effect of 4 grazing treatments differing in initial grazing date and stocking rate on the grazing behavior of spring-calving dairy cows during rotations 2 and 4 of the main grazing season ${ }^{1}$

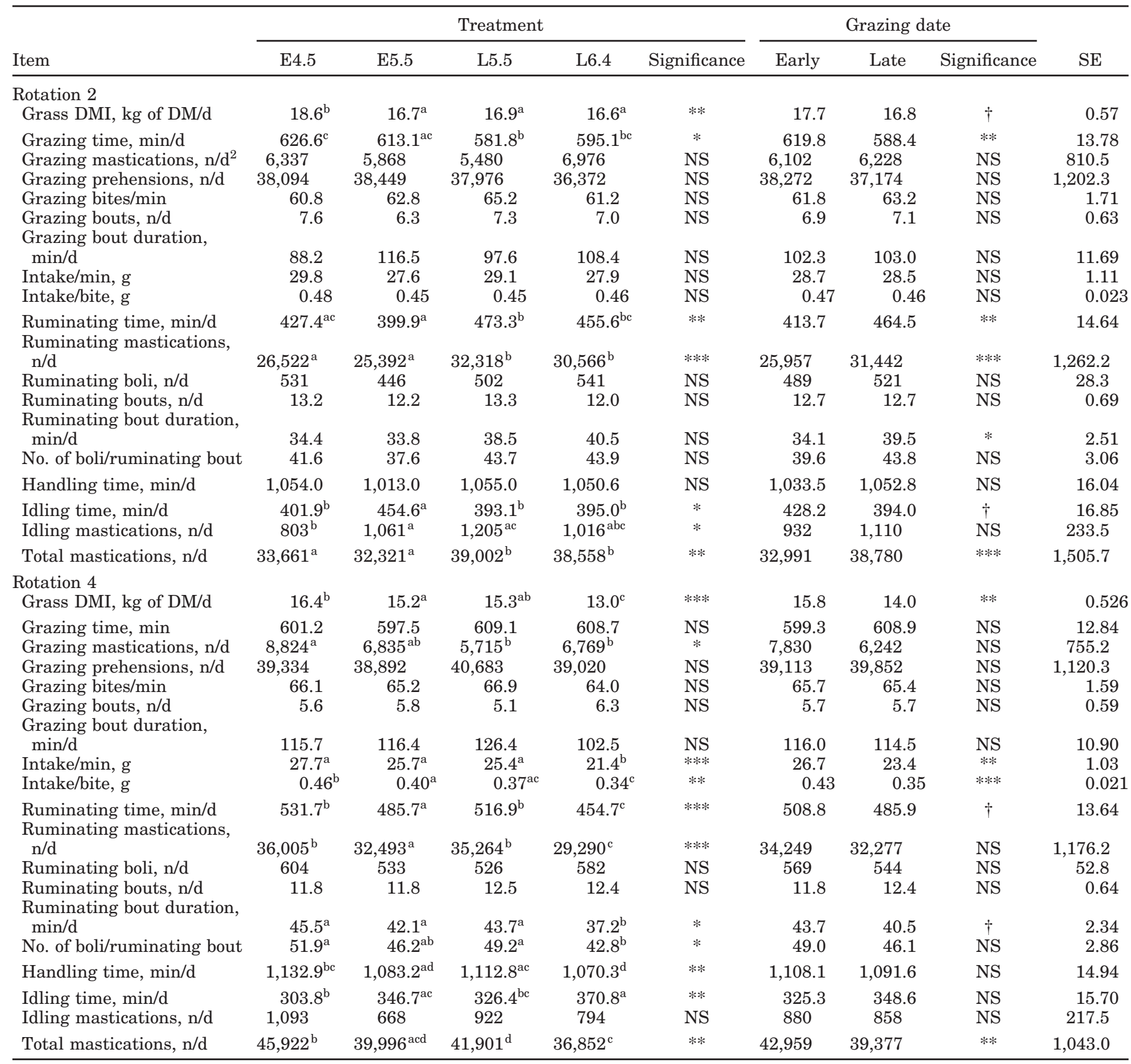

${ }^{\mathrm{a}-\mathrm{d}}$ Values in the same row not sharing a common superscript are different.

${ }^{1}$ E5.5 = early-grazed sward, high stocking rate (5.5 cows/ha); E4.5 = early-grazed sward, medium stocking rate 4.5 cows/ha); L6.4 = lategrazed sward, high stocking rate (6.4 cows/ha); L5.5 = late-grazed sward, medium stocking rate (5.5 cows/ha).

${ }^{2} \mathrm{n} / \mathrm{d}=$ number per day.

$\dagger P \leq 0.1 ; * P<0.05 ; * * P<0.01 ; * * * P<0.001$.

pared with animals grazing the early-grazed swards $(32,991$ mastications/d).

During R4, GDMI was less $(P<0.001)$ for animals grazing the $\mathrm{L} 6.4$ treatment $(13.0 \mathrm{~kg}$ of $\mathrm{DM} / \mathrm{d})$ than all other treatments (Table 5). The GDMI of animals graz- ing the L5.5 treatment ( $15.3 \mathrm{~kg}$ of DM/d) was not different from the GDMI of the E5.5 and E4.5 treatments, yet the intake of the E4.5 animals was greater $(+1.2$ $\mathrm{kg}$ of DM/d; $P<0.001$ ) than that of the E5.5 animals (15.2 $\mathrm{kg}$ of $\mathrm{DM} / \mathrm{d})$. During R4, treatment and grazing 
Table 6. Effect of 4 grazing treatments differing in initial grazing date and stocking rate on the milk production of spring-calving dairy cows during rotations 2 and 4 of the main grazing season ${ }^{1}$

\begin{tabular}{|c|c|c|c|c|c|c|c|c|c|}
\hline \multirow[b]{2}{*}{ Item } & \multicolumn{5}{|c|}{ Treatment } & \multicolumn{3}{|c|}{ Grazing date } & \multirow[b]{2}{*}{ SE } \\
\hline & E4.5 & E5.5 & L5.5 & L6.4 & Significance & Early & Late & Significance & \\
\hline \multicolumn{10}{|l|}{ Rotation 2} \\
\hline Milk yield, kg & $26.0^{\mathrm{b}}$ & $24.2^{\mathrm{a}}$ & $22.9^{\mathrm{a}}$ & $22.2^{\mathrm{a}}$ & **** & 25.1 & 22.6 & $* * *$ & 0.71 \\
\hline Fat, \% & 3.68 & 3.69 & 3.73 & 40.5 & NS & 3.69 & 3.89 & NS & 1.27 \\
\hline Protein, \% & 3.40 & 3.29 & 3.32 & 3.27 & NS & 3.35 & 3.30 & NS & 0.432 \\
\hline Lactose, \% & 4.71 & 4.69 & 4.75 & 4.77 & NS & 4.70 & 4.76 & NS & 0.384 \\
\hline SCM yield, kg & $23.6^{\mathrm{b}}$ & $21.6^{\mathrm{a}}$ & $20.9^{\mathrm{a}}$ & $20.9^{\mathrm{a}}$ & **** & 22.6 & 20.9 & $* *$ & 0.66 \\
\hline $\mathrm{BW}, \mathrm{kg}$ & 509 & 487 & 509 & 509 & NS & 498 & 509 & NS & 10.9 \\
\hline BCS & 2.76 & 2.81 & 2.77 & 2.65 & NS & 2.79 & 2.71 & NS & 0.047 \\
\hline \multicolumn{10}{|l|}{ Rotation 4} \\
\hline Milk yield, kg & $21.5^{\mathrm{b}}$ & $19.0^{\mathrm{a}}$ & $18.5^{\mathrm{a}}$ & $17.4^{\mathrm{c}}$ & **** & 20.3 & 18.0 & $* * *$ & 0.665 \\
\hline Fat, \% & 3.73 & 4.01 & 3.77 & 3.87 & NS & 3.87 & 3.82 & NS & 1.18 \\
\hline Protein, \% & $3.42^{\mathrm{b}}$ & $3.29^{\mathrm{a}}$ & $3.26^{\mathrm{a}}$ & $3.18^{\mathrm{a}}$ & *** & 3.36 & 3.22 & $* *$ & 0.40 \\
\hline Lactose, \% & $4.68^{\mathrm{bc}}$ & $4.58^{\mathrm{ad}}$ & $4.59^{\mathrm{ac}}$ & $4.50^{\mathrm{d}}$ & $* *$ & 4.63 & 4.55 & $*$ & 0.358 \\
\hline SCM yield, $\mathrm{kg}$ & $19.5^{\mathrm{b}}$ & $17.6^{\mathrm{a}}$ & $16.6^{\mathrm{a}}$ & $15.6^{\mathrm{c}}$ & $* * *$ & 18.6 & 16.1 & $* * *$ & 0.617 \\
\hline $\mathrm{BW}, \mathrm{kg}$ & 511 & 520 & 525 & 510 & NS & 516 & 518 & NS & 10.1 \\
\hline $\mathrm{BCS}$ & 2.62 & 2.63 & 2.64 & 2.57 & NS & 2.63 & 2.61 & NS & 0.044 \\
\hline
\end{tabular}

${ }^{\mathrm{a}-\mathrm{d}}$ Values in the same row not sharing a common superscript are different.

${ }^{1} \mathrm{E} 5.5$ = early-grazed sward, high stocking rate (5.5 cows/ha); E4.5 = early-grazed sward, medium stocking rate (4.5 cows/ha); L6.4 = late-grazed sward, high stocking rate (6.4 cows/ha); L5.5 = late-grazed sward, medium stocking rate $(5.5$ cows $/$ ha $)$; SCM yield = solids-corrected milk yield.

$* P<0.05 ; * * P<0.01 ; * * * P<0.001$.

date had no effect on grazing time. Intake/minute $(P<$ $0.01)$, intake/bite $(P<0.001)$, and total mastications $(P$ $<0.001)$ were greater for animals grazing the earlygrazed sward ( $26.7 \mathrm{~g}, 0.43 \mathrm{~g}$, and 42,959 mastications/d, respectively) than those grazing the late-grazed sward (23.4 g, $0.35 \mathrm{~g}$, and 39,377 mastications/d, respectively).

Animals from the L6.4 treatment had the lowest $(P$ $<0.001)$ ruminating time and number of ruminating mastications (455 min/d and 29,290 mastications/d, respectively) compared with all other treatments. The ruminating bout duration was less for the L6.4 animals $(37 \mathrm{~min} / \mathrm{d})$ than all other treatments $(44 \mathrm{~min} / \mathrm{d})$. The number of boli/ruminating bout for the L6.4 animals (43 boli) was not significantly different from the E5.5 treatment (46 boli) but was significantly less than the E4.5 and L5.5 treatments (51 boli), which did not differ significantly.

Handling time was highest for the animals from the E4.5 treatment $(1,133 \mathrm{~min} / \mathrm{d})$ and lowest for the L6.4 animals $(1,070 \mathrm{~min} / \mathrm{d})$; the E5.5 and L5.5 treatments had intermediate values $(1,098 \mathrm{~min} / \mathrm{d})$. Conversely, the L6.4 animals ( $371 \mathrm{~min} / \mathrm{d}$ ) had the highest idling time, whereas the E4.5 animals had the lowest (304 $\mathrm{min} / \mathrm{d}$ ), and the E5.5 and L5.5 treatments had intermediate values $(337 \mathrm{~min} / \mathrm{d})$.

\section{Animal Production}

During R2, milk and SCM yields were larger $(P<$ 0.001 ) for the E4.5 treatment compared with the other
3 treatments, which did not differ significantly (Table 6). There was no significant difference in fat, protein, and lactose concentration, BW, or BCS between treatments. During R4, the E4.5 treatment animals recorded the greatest $(P<0.001)$ milk and SCM yields, as well as a greater protein concentration $(3.42 \% ; P<0.001)$. Lactose concentration was greater $(P<0.01)$ for the E4.5 and L5.5 animals (4.64\%) when compared with their counterparts grazing the E5.5 and L6.4 treatments $(4.54 \%)$. There was no significant difference in BW and BCS between treatments in R4.

\section{DISCUSSION}

Understanding the interaction between the sward and the animal is a fundamental element of grassland research. Maintaining a balance between optimizing dairy cow performance and maintaining sward nutritive value is a dual objective of efficient grassland management. The main objective of this study was to investigate the effect of initial spring grazing date and stocking rate imposed on sward structure as well as the grazing behavior and animal production of spring-calving dairy cows during the main grazing season.

\section{Sward Characteristics}

Previous studies have highlighted the beneficial effects of defoliating pastures in early spring on sward quality during the main grazing season (O'Donovan et 
al., 2004). Herbage chemical composition is frequently influenced by the regrowth age (Wilman et al., 1996), seasonal accumulations of dead herbage (L'Huillier, 1987), and increases in sward leaf proportion. The lategrazed swards supported a greater $\mathrm{HM}>4.0 \mathrm{~cm}$ than the early-grazed swards in R2 $(+1,055 \mathrm{~kg}$ of DM/ha). Similar to that reported by Holmes et al. (1992), the late-grazed swards (high HM) contained larger proportions of senescent material because dead DM yield $<4.0$ $\mathrm{cm}$ was on average $496 \mathrm{~kg}$ of DM/ha greater on the lategrazed swards over the 2 measurement periods ( $309 \mathrm{~kg}$ in R2 and $683 \mathrm{~kg}$ in R4). Holmes et al. (1992) reported that this was because of a greater average age of the plant tissues; it may also be because of reduced light penetration in the lower grazing horizon. Additionally, the greater pregrazing HM present on the late-grazed swards during R2 may have shaded daughter tillers and caused their atrophy (Ong et al., 1978), because during R4 there were substantially fewer tillers $/ \mathrm{m}^{2}$ on the late-grazed sward $\left(-1,996\right.$ tillers $\left./ \mathrm{m}^{2}\right)$.

Because the late-grazed sward had a greater pregrazing sward height $(+4.0 \mathrm{~cm})$ and pregrazing $\mathrm{HM}>4.0$ $\mathrm{cm}$, during R2, higher pregrazing ETH, ESH, and FLL were expected. Accordingly, the postgrazing ETH, ESH, and FLL values were greater for the late-grazed sward. During R2, a lesser proportion of the late-grazed swards were utilized. When the leaf-to-stem ratio is considered, the leaf proportion of the early-grazed sward was larger $(+0.7)$ than that of the late-grazed sward. This indicates that when swards are defoliated earlier in spring (February to March), the pregrazing sward height/extended tiller height is reduced, but a larger proportion of leaf material accumulates in the sward. This finding is similar to that reported by O'Donovan et al. (2004). As the study progressed (R4), the cumulative effect of the high stocking rate $(6.4$ cows/ha) on the late-grazed sward resulted in a pregrazing ETH and FLL similar to that of the early-grazed sward. When the postgrazing measurements were recorded, the values for the high stocking rate treatments were less than for the treatments stocked at a medium stocking rate.

\section{Animal Grazing Behavior, GDMI, and Milk Production}

Similar to that reported by Delagarde et al. (2000), this study found no effect of DHA on grazing time or bite rate. Although mean grazing time in this study was comparable to the grazing times reported by Rook et al. (1994), the values reported are greater than those recorded by previous studies (Phillips and Leaver, 1986; McCarthy et al., 2007) using similar measurement techniques. During R2, grazing time was greater for the animals grazing the early-grazed sward $(+34.3 \mathrm{~min} /$ d) compared with their counterparts grazing the lategrazed sward and was reflected in a greater GDMI. Grazing time during R4 was not influenced by the initial spring grazing date or stocking rate. Herbage intake of animals has been shown to be the product of grazing time, bite rate (bites/min), and herbage intake/bite (Holmes, 1989). The GDMI of the L6.4 animals was restricted during $\mathrm{R} 4$, because the cumulative effect of a high stocking rate on the sward resulted in a low DHA. A difference in intake/bite along with similar grazing times tended toward differences in intake/minute between the early- $(26.7 \mathrm{~g})$ and late- $(23.4 \mathrm{~g})$ grazed swards. However, intake/bite increased with the E4.5 and L5.5 treatments (0.42 g) compared with the E5.5 and L6.4 treatments $(0.37 \mathrm{~g})$ and also tended to increase on the early-grazed swards $(+0.08 \mathrm{~g})$ because of a greater DHA. There were differences in DHA but no differences in grazing time or sward quality, which suggests that a difference in pregrazing sward height may have resulted in larger intakes by animals stocked at a medium stocking rate. McGilloway et al. (1999) found that both intake/bite and total DMI increased with higher pregrazing sward heights. In R2, the pregrazing sward height of the early-grazed sward was less ( -4.0 $\mathrm{cm}$ ) than that of the late-grazed sward. Animals grazing the early-grazed sward achieved a greater proportion of sward height removal and also had lower postgrazing sward heights and greater herbage utilization.

Because rotationally grazed animals are selective grazers (Bao, 1992), leaf has to be selected from the sward; thus, it may be of interest to consider leaf allowance. The larger GDMI of the E4.5 treatment during $\mathrm{R} 4$ is probably due to the greater DHA and ultimately the larger leaf allowance available to the animals, which were reflected in superior milk production performance. Differences during R2 in GDMI and sward quality were not reflected as major determinants of intake/ min or intake/bite. This indicates that animals may adjust to their given environment. The pregrazing extended sheath height was $+6.9 \mathrm{~cm}$ higher for the latergrazed swards than the early-grazed swards. Therefore, it is difficult for the grazing animal to achieve high GDMI because the stem proportion of the sward is elevated in the grazing horizon, creating a physical barrier for grazing animals (Wade et al., 1989). Barrett et al. (2000) reported a mean bite depth of $32 \%$ of ETH, whereas Wade et al. (1989) reported that dairy cows consistently removed $34 \%$ of tiller height. In the present study, animals grazing the early-grazed sward removed $48 \%$ of ETH compared with $44 \%$ of ETH removed by animals grazing the late-grazed sward. A larger stocking rate results in greater grazing severity (O'Donovan et al., 2004), which can ultimately improve sward structure. This supposition was supported by the results of 
$\mathrm{R} 4$, because the postgrazing sward heights of the swards stocked at a high stocking rate were $1.3 \mathrm{~cm}$ less than those stocked at a medium stocking rate $(6.6 \mathrm{~cm})$. Increased grazing severity tended to increase sward quality, because the leaf proportion of the highly stocked swards was $0.04 \%$ greater than that of swards stocked at a medium stocking rate $(0.59 \%)$. The increase in sward leaf content, however, was not sufficient to compensate for the smaller DHA offered, as GDMI decreased by approximately $11 \%$.

When pastures were defoliated in early spring, a superior-quality sward (greater OMD, greater $\mathrm{CP}$, and lesser NDF) resulted during R2. However, the greater $\mathrm{CP}$ content of the early-grazed swards may be attributable to the extra $60 \mathrm{~kg}$ of N/ha that it received following its first defoliation (Astigarraga et al., 2002). Delaying the initial turnout date to mid-April resulted in a poorer quality sward being offered to the L6.4 and L5.5 animals, which culminated in reduced milk production. When efficiency of production during $\mathrm{R} 2$ is considered, the E4.5, E5.5, L5.5, and L6.4 treatments produced $1.40,1.45,1.37$, and $1.33 \mathrm{~kg}$ of milk/kg of GDMI, respectively. Conversion efficiency was significantly greater in the E4.5 and E5.5 treatments $(+0.07 \mathrm{~kg}$ of milk $/ \mathrm{kg}$ of GDMI; $P<0.01$ ) than the L5.5 and L6.4 treatments. This may be because of the superior sward quality of the early-grazed sward, because in $\mathrm{R} 4$ when all differences in sward quality had dissipated, there was no difference in the efficiency of milk production $(1.28 \mathrm{~kg}$ of milk/kg of GDMI) between animals grazing the early and late-grazed swards.

Although the beneficial effects achieved by grazing pastures early in spring had disappeared by R4, the initial advantage of early spring grazing on both sward and animal effects make it an important avenue through which animal performance from grazing systems can be advanced.

\section{CONCLUSIONS}

Optimizing dairy cow performance while maintaining sward nutritive value is a key objective of efficient grassland management in any pasture-based system. Delaying the turnout date from early February to mid-April had a major effect on sward quality and structure at the start of the main grazing season. The reduction in sward quality and inferior sward structure of the late-grazed sward was reflected in lesser milk and SCM yields as well as shorter grazing times. Even though large differences between swards were recorded during $\mathrm{R} 2$, the effect of the initial grazing date on the sward had diminished by R4.

In contrast to R2, animal performance and behavioral differences in R4 were influenced by the DHA, which was a direct consequence of the stocking rate imposed. Stocking animals at a medium stocking rate on the early-grazed sward resulted in increased milk protein concentration and increased milk and SCM yields. The results of this study suggest that increased animal performance and improved grazing behavior characteristics can initially be achieved on pastures grazed in early spring (February to March). As the grazing season progresses, however, the effect of the initial grazing date is reduced, because swards first grazed in April were of similar quality and structure as those primarily grazed in February. Therefore, to optimize animal production while simultaneously maintaining sward quality, pastures should be grazed in early spring.

\section{ACKNOWLEDGMENTS}

The authors wish to thank M. Feeney, F. Flynn, J. Nash, J. O'Dwyer, and N. Galvin for their technical assistance, as well as all the Moorepark farm staff for their care of the experimental animals and assistance with measurements taken during the study.

\section{REFERENCES}

Astigarraga, L., J. L. Peyraud, and L. Delaby. 2002. Effect of nitrogen fertiliser rate and protein supplementation on the herbage intake and the nitrogen balance of grazing dairy cows. Anim. Res. 51:279-293.

Bao, J. 1992. Grazing behaviour of dairy cows at pasture and behavioural observations in winter housing. Ph.D. Thesis University College Cork, Ireland.

Barrett, P. D., A. S. Laidlaw, H. Christie, and C. S. Mayne. 2000. Herbage intake potential and bite dimensions of dairy cows when grazing a one-day paddock. Pages 97-98 in Grazing Management. BGS Occasional Symp. No. 34. A. J. Rook and P. D. Penning, ed. British Grassland Society, Reading, UK.

Delaby, L., and J. L. Peyraud. 1998. Effect d'une réduction simultanée de la fertilisation azotée et du chargement sur les performances des vaches laitières et la valorisation du pâturage. Ann. Zootech. 47:17-39.

Delagarde, R., J. L. Peyraud, and L. Delaby. 2000. Influence of herbage allowance on intake and behaviour of dairy cows grazing perennial ryegrass swards in autumn. Pages 101-102 in Grazing Management. BGS Occasional Symp. No. 34. A. J. Rook and P. D. Penning, ed. British Grassland Society, Reading, UK.

Dillon, P. 1993. The use of n-alkanes as markers to determine intake, botanical composition of available or consumed herbage in studies of digesta kinetics with dairy cows. Ph.D. Thesis National University of Ireland, Dublin, Ireland.

Dillon, P., J. R. Roche, L. Shalloo, and B. Horan. 2005. Optimising financial return from grazing in temperate pastures. Pages pp. 131-147 in Utilisation of Grazed Grass in Temperate Animal Systems. J. J. Murphy, ed. World Grassl. Congr. 2005, Cork, Ireland. Wageningen Acad. Publ., Wageningen, the Netherlands.

Dillon, P., and G. Stakelum. 1989. Herbage and dosed alkanes as a grass management technique for dairy cows. Irish J. Agric. Res. 8:104. (Abstr.)

Holmes, W. 1989. The utilisation of pasture. Pages 181-192 in Ruminant Nutrition: Recommended Allowances and Feed Tables. R. Jarrige, ed. Inst. Natl. Rech. Agron, Paris, France.

Holmes, C. W., C. J. Hoogendoorn, M. P. Ryan, and A. C. P. Chu. 1992. Some effects of herbage composition, as influenced by previous grazing management, on milk production by cows grazing on 
ryegrass/white clover pastures. 1. Milk production in early spring: Effects of different regrowth intervals during the preceding winter period. Grass Forage Sci. 47:309-315.

Jewiss, O. R. 1993. Shoot development and number. Pages 99-120 in Sward Measurement Handbook. 2nd ed. A. Davies, R. D. Baker, S. A. Grant, and A. S. Laidlaw, ed. The British Grassland Society, Reading, UK

Kennedy, E., M. O'Donovan, J. P. Murphy, L. Delaby, and F. P. O'Mara. 2005. Effects of grass pasture and concentrate based feeding systems for spring calving dairy cows in early spring on lactation performance. Grass Forage Sci. 60:310-318.

Kennedy, E., M. O'Donovan, J. P. Murphy, F. P. O’Mara, and L. Delaby. 2006. The effect of spring grazing date and subsequent stocking rate on the grazing management, grass dry matter intake and milk production performance of dairy cows during the midgrazing season. Grass Forage Sci. 61:375-384.

Laca, E. A., E. D. Ungar, N. Seligman, and M. W. Demment. 1992 Effects of sward height and bulk density on bite dimensions of cattle grazing homogenous swards. Grass Forage Sci. 47:91-102.

L'Huillier, P. J. 1987. Effect of dairy cattle stocking rate and degree of defoliation on herbage accumulation and quality in ryegrasswhite clover pasture. N. Z. J. Agric. Res. 30:149-157.

Lowman, B. G., N. Scott, and S. Somerville. 1976 Condition Scoring of Cattle. Rev. ed. Bull. No. 6. East of Scotland College of Agriculture, Edinburgh, UK.

Mayes, R. W., C. S. Lamb, and P. A. Colgrove. 1986. The use of dosed herbage n-alkanes as markers for the determination of herbage intake. J. Agric. Sci. (Camb.) 107:161-170.

McCarthy, S., B. Horan, M. Rath, M. Linnane, P. O'Connor, and P. Dillon. 2007. The influence of strain of Holstein-Friesian and pasture-based feeding system on grazing behaviour, intake and milk production. Grass Forage Sci. 62:13-26.

McGilloway, D. A., A. Cushnahan, A. S. Laidlaw, and D. J. Kilpatrick. 1999. The relationship between level of sward height reduction of a rotationally grazed sward and short-term intake rates of dairy cows. Grass Forage Sci. 54:116-126.

Morgan, D. J., G. Stakelum, and J. O'Dwyer. 1989. Modified neutral detergent cellulose digestibility procedure for use with the "Fibertec" system. Irish J. Agric. Res. 28:91-92.

Newman, J. A., A. J. Parsons, and P. D. Penning. 1994. A note on the behavioural strategies used by grazing animals to alter their intake rates. Grass Forage Sci. 49:502-505.

O'Donovan, M., L. Delaby, and J. L. Peyraud. 2004. Effect of time of initial grazing date and subsequent stocking rate on pasture production and dairy cow performance. Anim. Res. 53:489-502.
Ong, C. K., C. Marshall, and G. R. Sagar. 1978. The physiology of tiller death in grasses: 2 . Causes of tiller death in a grass sward. J. Br. Grassl. Soc. 33:205-211.

Peyraud, J. L., E. A. Comeron, M. H. Wade, and G. Lemaire. 1996. The effect of daily herbage allowance, herbage mass and animal factors upon herbage intake by grazing dairy cows. Ann. Zootech. 45:201-217.

Phillips, C. J. C., and J. D. Leaver. 1986. Seasonal and diurnal variation in the grazing behaviour of dairy cows. Pages 98-104 in Grazing. Occasional Symp. No. 19. J. Frame, ed. The British Grassland Society, Reading, UK.

Rook, A. J., C. A. Huckle, and P. D. Penning. 1994. Effects of sward height and concentrate supplementation on the ingestive behaviour of spring-calving dairy cows grazing grass-clover swards. Appl. Anim. Behav. Sci. 40:101-112.

Rook, A. J., and P. D. Penning. 1991. Synchronisation of eating, ruminating and idling activity by grazing sheep. Appl. Anim. Behav. Sci. 32:157-166.

Rutter, S. M. 2000. 'Graze': A program to analyse recordings of jaw movements of ruminants. Behav. Res. Methods Instrum. Comput. 32:86-92.

Rutter, S. M., R. A. Champion, and P. D. Penning. 1997. An automatic system to record foraging behaviour in free-ranging ruminants. Appl. Anim. Behav. Sci. 54:185-195.

SAS Institute. 2002. User's Guide: Statistics. SAS Institute, Inc., Cary, NC.

Shalloo, L., P. Dillon, J. O'Loughlin, M. Rath, and M. Wallace. 2004. Comparison of a pasture-based system of milk production on a high rainfall, heavy-clay soil with that on a lower rainfall, freedraining soil. Grass Forage Sci 59:157-168.

Tyrell, H. F., and J. T. Reid. 1965. Prediction of the energy value of cows' milk. J. Dairy Sci. 48:1215-1233.

Urban, B., and J. P. Caudal. 1990. Herbometre automatise (Automatic platementer). Pages 57-59 in Les journées de la mesure: électronique, informatique, automatique, Port Leucate, France. INRA, Paris, France.

Van Soest, P. J. 1963. Use of detergents in the analysis of fibrous feeds. II. A rapid method for the determination of fiber and lignin. J. AOAC 46:829-835.

Wade, M. H., J. L. Peyraud, G. Lemaire, and E. A. Cameron. 1989. The dynamics of daily area and depth of grazing and herbage intake of cows in a five-day paddock system. Pages 1111-1112 in Proc. 16th Int. Grassl. Congr., Nice, France. A. Capillon, ed. INRA, Paris, France.

Wilman, D., Y. Gao, and M. A. K. Altimimi. 1996. Differences between related grasses, times of year and plant parts in digestibility and chemical composition. J. Agric. Sci. (Camb.) 127:311-318. 